\title{
Organization and Chromosomal Distribution of Histone Genes and Transposable Rex Elements in the Genome of Astyanax bockmanni (Teleostei, Characiformes)
}

\author{
Sandro N. Daniel ${ }^{a}$ Manolo Penitente ${ }^{a}$ Duílio M.Z.A. Silva ${ }^{b}$ \\ Diogo T. Hashimoto $^{c}$ Daniela C. Ferreira ${ }^{d}$ Fausto Foresti $^{b}$ \\ Fábio Porto-Forestia \\ a'Departamento de Ciências Biológicas, Faculdade de Ciências, Universidade Estadual Paulista (UNESP), Bauru, \\ ${ }^{\text {b}}$ Departamento de Morfologia, Instituto de Biociências, UNESP, Botucatu, 'Centro de Aquicultura de Jaboticabal \\ (CAUNESP), UNESP, Jaboticabal, and d Instituto de Biociências, Universidade Federal de Mato Grosso (UFTM), \\ Cuiabá, Brazil
}

\section{Key Words}

Histone genes - Neotropical fish - Repetitive DNA ·

Transposable Rex elements

\begin{abstract}
An important feature of eukaryotic organisms is the number of different repetitive DNA sequences in their genome, a feature not observed in prokaryotes. These sequences are considered to be important components for understanding evolutionary mechanisms and the karyotypic differentiation processes. Thus, we aimed to physically map the histone genes and transposable elements of the Rex family in 6 fish populations of Astyanax bockmanni. FISH results using a histone $\mathrm{H} 1$ gene probe showed fluorescent clusters in 2 chromosome pairs in all 6 samples analyzed. In contrast, FISH with a histone $\mathrm{H} 3$ probe showed conspicuous blocks in 4 chromosomes in 5 of the 6 populations analyzed. The sixth population revealed 7 chromosomes marked with this probe. Probes for the transposable elements Rex 1 and Rex6 showed small sites dispersed on most chromosomes of the 6 populations, and the Rex3 element is located in a big block concentrated in only 1 acrocentric chromosome of 2 popula-
\end{abstract}

\section{KARGER 125}

() 2015 S. Karger AG, Basel

$1424-8581 / 15 / 1464-0311 \$ 39.50 / 0$

E-Mail karger@karger.com

www.karger.com/cgr tions. As for the other populations, a Rex3 probe showed large blocks in more than 1 chromosome. Fish from Alambari and Campo Novo Stream have Rex3 elements dispersed along most of the chromosomes. Additionally, the conspicuous signals of $\operatorname{Rex} 1, \operatorname{Rex} 3$, and Rex 6 were identified in the acrocentric $B$ microchromosome of $A$. bockmanni found only in individuals of the Alambari River. Thus, we believe that different mechanisms drive the spread of repetitive sequences among the populations analyzed, which appear to be organized differently in the genome of $A$. bockmanni. The presence of transposable elements in the B chromosome also suggests that these sequences could play a role in the origin and maintenance of the supernumerary element in the genome of this species.

(c) 2015 S. Karger AG, Basel

Eukaryotic organisms are characterized by carrying a large amount of repetitive DNAs [Bueno et al., 2013; Chalopin et al., 2015] which are known to contain high variability in their nucleotide composition, number of copies, function, distribution, and organization patterns in the genome of the species [Charlesworth et al., 1994]. Ac- 
cording to Nagoda et al. [2005], these DNA sequences are classified into 3 main classes: (1) tandem repeats, which include satellite, minisatellite, and microsatellite DNA sequences, (2) transposable elements, which include transposable and retrotransposable elements, and (3) multigene families, which can be represented by repetitive coding sequences such as histone and ribosomal genes.

Studies on the organization and physical mapping of different repetitive DNA sequences allowed significant advances in the characterization of the biodiversity and evolution of ichthyofauna [Vicari et al., 2010] and a greater knowledge of the organization, diversification, evolution, and function of repetitive sequences in the genomes of different vertebrate groups [Gursel et al., 2003; Chalopin et al., 2015]. However, most gene mapping studies have often targeted only the location of rDNA sequence sites, resulting in little information on other types of sequences, including the families of histones and Rex transposons [Cioffi et al., 2010; Ferreira et al., 2011a, b; Valente et al., 2011; Yano et al., 2014].

Thus, the present study reports the mapping of repetitive sequences of histone family components ( $\mathrm{H} 1$ and H3) and transposable elements of the Rex family (Rex1, Rex3, and Rex6) in 6 natural populations of Astyanax bockmanni, a neotropical fish that occurs throughout Brazil and has a number of different polymorphism-related cytogenetic markers, including the presence of $\mathrm{B}$ chromosome morphotypes. Moreover, there is a lack of information at the population level, where a number of populations do not have karyotypic records. In this context, we aim to contribute information about distribution patterns on chromosomes, homologies, and evolutionary relationships between these elements in the genome of A. bockmanni.

\section{Materials and Methods}

\section{Sampling and Mitotic Chromosomes}

A total of 169 individuals of the species A. bockmanni were sampled from 6 natural populations (online suppl. table 1; see www.karger.com/doi/10.1159/000441613 for all online suppl. material) of 2 major hydrographic river basins, Tietê and $\mathrm{Pa}$ ranapanema, of the state of São Paulo, Brazil. Following morphological identification, the specimens were subjected to mitosis stimulation according to Oliveira et al. [1988]. The chromosome preparations and cytogenetic analysis were performed according to Foresti et al. [1993] based on direct preparations of kidney cell suspensions. The C-banding technique was applied according to Sumner [1972], with some adaptations. The chromosome morphology was determined on the basis of the arm ratio according to Levan et al. [1964], and chromosomes were classified as meta- centric (m), submetacentric (sm), subtelocentric (st), and acrocentric (a) and arranged in descending order of size for the organization of the karyotype. After cytogenetic analysis of the specimens, the top 8 preparations of each sampled site were used for FISH.

\section{Repetitive Probes and FISH Experiments}

For the isolation and amplification of partial sequences of the histone $\mathrm{H} 1$ and $\mathrm{H} 3$ genes, degenerate primers $\mathrm{H} 1 \mathrm{~F}$ (5'-ATGGCAGAARYCGCMCCAGC- $\left.3^{\prime}\right)$ and H1 R (5'-TACTTCTTCTTGGGSGCTGC-3') [Hashimoto et al., 2011], and H3 F (5'-ATGGCTCGTACCAAGCAGACVGC-3') and H3 R (5'-ATATCCTTRGGCATRGTGAC- $3^{\prime}$ ) [Colgan et al., 1998] were used. The primers for the transposable elements were RTX1-F1 (5'-TTCTCCAGTGCCTTCAACACC-3') and RTX1-R1 (5'-TTCCTTAAAAAATAGAGTCTGCTC-3') for Rex1 [Volff et al., 1999, 2000], RTX3-F1 (5'-TACGGAGAAAACCCATTTCG-3') and RTX3-R1 ( $5^{\prime}$-AAAGTTCCTCGGTGGCAAGG-3') for Rex3 [Volff et al., 1999, 2000], and REX6-F (5'-TAAAGCATACATGGAGCGCCAC- $\left.{ }^{\prime}\right)$ and REX6-R (5'-GGTCCTCTACCAGAGGCCTGGG$3^{\prime}$ ) for Rex6 [Volff et al., 2001].

The hybridization conditions were the same for every specimen analyzed, and high stringency conditions were applied following the procedures described in Pinkel et al. [1986]. The probes were labeled with biotin-16-dUTP and digoxigenin-11-dUTP, and hybridization signals were developed using avidin-FITC and antidigoxigenin-rhodamine. The images were captured by a digital camera attached to a fluorescence microscope (Olympus BX50). Approximately 20 metaphase spreads of each individual were analyzed to confirm the signals obtained. The assembly of karyotypes, maintenance, and the brightness and contrast of the images were characterized using Adobe Photoshop CS5 software.

\section{Results}

All analyzed populations of $A$. bockmanni presented $2 \mathrm{n}=50$ chromosomes and karyotype formulas consisting of $8 m+8 s m+18 s t+16 a$ (Alambari Stream), $4 m+7 s m+$ $8 s t+6 a$ (Véu de Noiva Waterfall), $6 m+14 s m+14 s t+18 a$ (Batalha River), $6 \mathrm{~m}+14 \mathrm{sm}+14 \mathrm{st}+16 \mathrm{a}$ (Campo Novo Stream), $6 \mathrm{~m}+14 \mathrm{sm}+14 \mathrm{st}+16 \mathrm{a}$ (Barra Seca Stream), and $8 m+14 s m+12 s t+16 a$ (Capivara River), all previously described by Daniel et al. [2015]. In individuals of the Alambari Stream population, 0-2 supernumerary meta- and acrocentric microchromosomes were also identified in the genome, as previously described by Daniel et al. [2015].

In situ hybridization with a histone $\mathrm{H} 1$ probe in populations of $A$. bockmanni showed 2 chromosome pairs marked with the predominance of a metacentric pair in the 6 populations reported (fig. 1). The histone $\mathrm{H} 3$ gene is present in 2 pairs in Campo Novo, Barra Seca, Batalha, Capivara and Véu de Noiva populations (fig. 2b-f). Conversely, the Alambari population showed 7 hybridization 

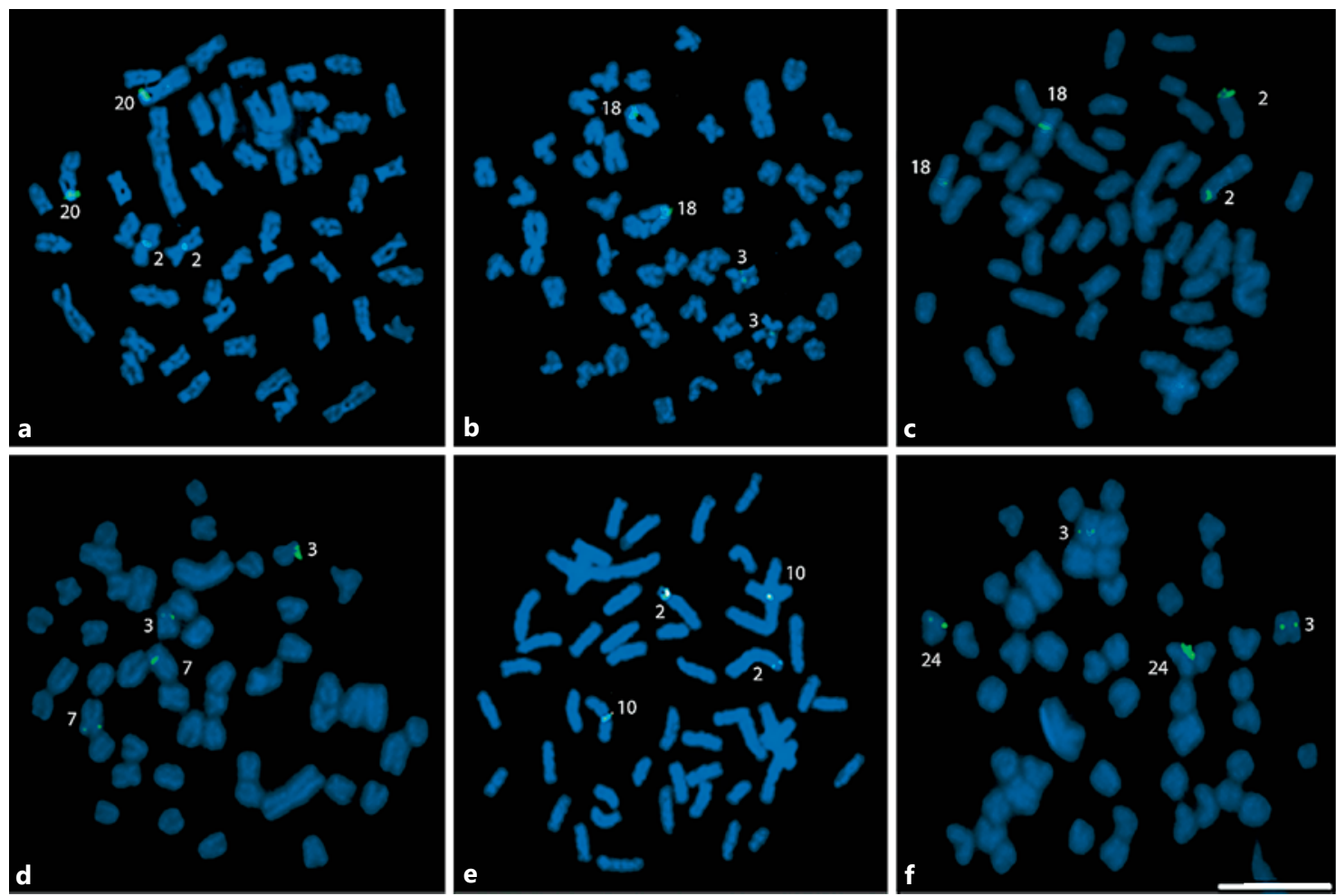

Fig. 1. Somatic metaphases from individuals of 6 populations of $A$. bockmanni after in situ hybridization using the histone $\mathrm{H} 1$ gene probe. a Alambari Stream. b Campo Novo Stream. c Barra Seca Stream. d Batalha River. e Capivara River. f Véu de Noiva Waterfall. Green signals indicate the hybridization sites with the probe, and numbers indicate the chromosomes marked. Bar $=10 \mu \mathrm{m}$.

signals for histone $\mathrm{H} 3$ (fig. 2a). FISH with probes for transposons Rex 1 and Rex6 showed small sites in most chromosomes of the 6 populations analyzed, with signal clusters almost completely covering most of the chromosomes (figs. 3, 4). However, larger blocks of these markings were recorded in only some chromosomes of the Alambari and Campo Novo populations (Rex1 in fig. 3a, b) and Alambari and Capivara populations (Rex6 in fig. 4a, e).

The transposon Rex3 only presented a dispersed pattern on the chromosomes of Alambari and Campo Novo populations (online suppl. fig. 1a, b). In the Capivara population the probe marked large blocks and small dispersed sites along the chromosomes (online suppl. fig. 1e). In Véu de Noiva, Batalha and Barra Seca populations, large fluorescent blocks on specific sites were generally located in the terminal region of the chromosomes (online suppl. fig. 1c, d, f). Interestingly, large blocks of Rex3 sequences were identified in the telomeric regions of only 1 acrocentric chromosome pair from the Barra Seca pop-

Histone Genes and Transposable Elements in Astyanax bockmanni ulation, while median-sized sites were observed in at least 3 pairs of acrocentric chromosomes from the Batalha population (online suppl. fig. 1c, d).

In addition to the signals found on autosomes, sequences of Rex $1, \operatorname{Rex} 3$, and Rex6 were also observed along the $\mathrm{B}$ chromosome of individuals collected from the Alambari population (figs. 3a, 4a; online suppl. fig. 1a).

\section{Discussion}

The 6 populations of A. bockmanni showed a diploid number of $2 n=50$ chromosomes in all individuals analyzed, as previously observed for distinct populations of this species [Kavalco et al., 2009; Fernandes et al., 2010; Hashimoto and Porto-Foresti, 2010; Hashimoto et al., 2011; Daniel et al., 2012, 2015; Silva et al., 2013]. Similar patterns were also observed in other species of the genus [Pansonato-Alves et al., 2013a; Silva et al., 2014]. Additionally, individuals of the Alambari population present- 

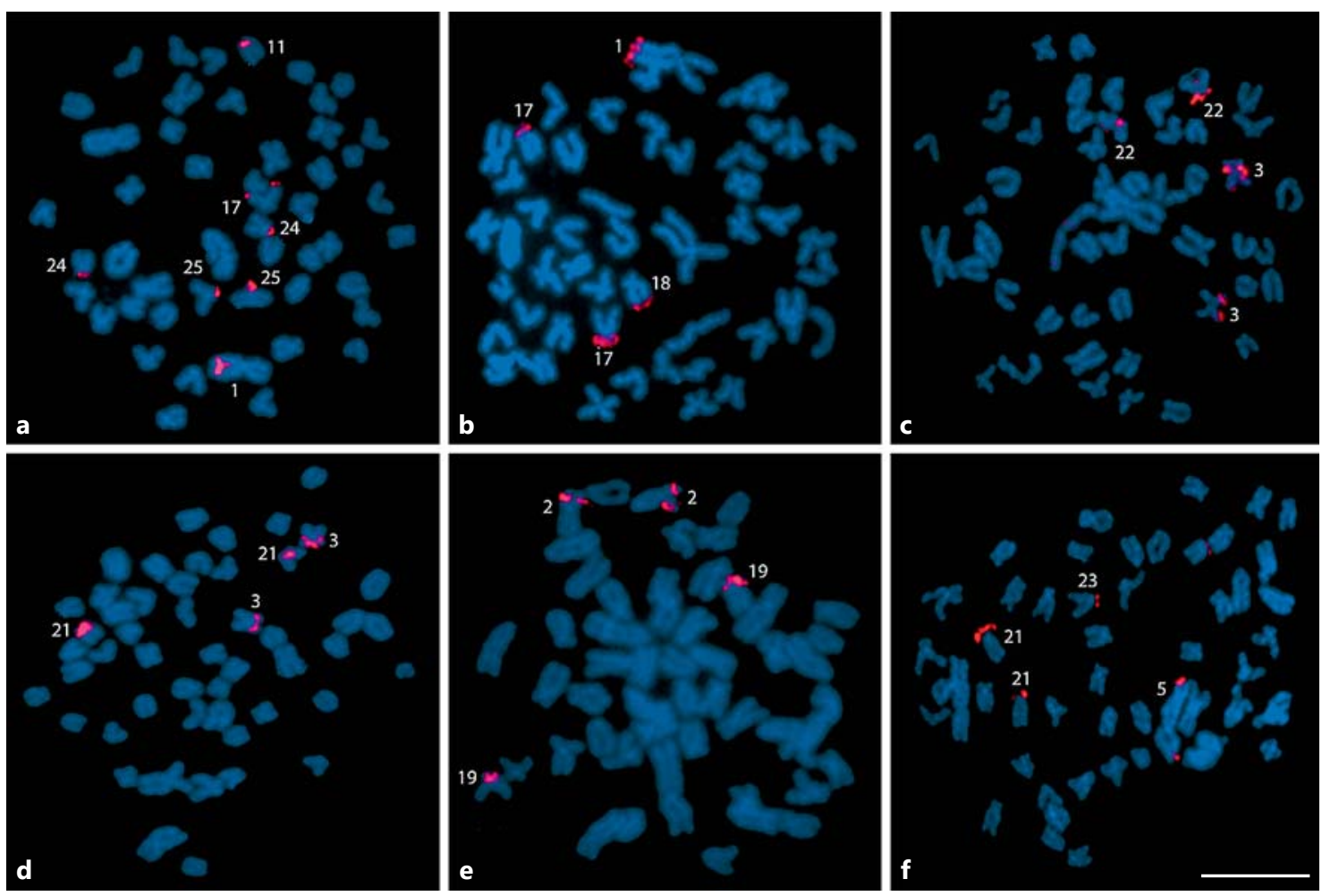

Fig. 2. Somatic metaphases from individuals of 6 populations of $A$. bockmanni after in situ hybridization using the histone H3 gene probe. a Alambari River. b Campo Novo Stream. c Barra Seca Stream. d Batalha River. e Capivara River. $\mathbf{f}$ Véu de Noiva Waterfall. Red signals indicate the hybridization sites with the probe, and numbers indicate the chromosomes marked. Bar $=10 \mu \mathrm{m}$.

ed $0-2$ partially or fully heterochromatic metacentric and/or acrocentric supernumerary microchromosomes in their genome, with a morphologic behavior that was previously observed by Hashimoto et al. [2011] and Daniel et al. [2012, 2015].

We observed the occurrence of only 4 chromosomes tagged with the probe for histone H1. This could indicate a conservative behavior of this sequence in the genome of the species, as observed by Hashimoto et al. [2011] and Silva et al. [2013]. Hashimoto et al. [2011] observed the recurrent labeling of histone $\mathrm{H} 1$ sites associated with the $5 \mathrm{~S}$ rDNA on a metacentric chromosome pair in A. bockmanni, A. fasciatus, and A. altiparanae. Similar results were reported in other populations of $A$. bockmanni and A. fasciatus [Silva et al., 2013; Pansonato-Alves et al., 2013a], and according to Pansonato-Alves et al. [2013a], these features converge to a common ancestry and a conservative behavior. This hypothesis was already proposed by Hashimoto et al. [2011] and was subsequently corroborated and strengthened by Silva et al. [2013, 2014] and Pansonato-Alves et al. [2013a]. The idea that these genes could evolve in concert was also reported and discussed for species in other fish groups [Hashimoto et al., 2012; Pansonato-Alves et al., 2013b; Utsunomia et al., 2014].

Similarly to histone $\mathrm{H} 1$, the histone $\mathrm{H} 3$ gene is located on 2 chromosome pairs in 5 of the 6 populations analyzed. However, individuals of the Alambari population exhibited 7 chromosomes marked with the $\mathrm{H} 3$ gene probe, contrasting with the pattern apparently observed in individuals of the other studied populations of this species. Thus, the results in the population of $A$. bockmanni show a pattern of markings in the form of blocks concentrated in a few well-defined chromosomes, usually in pairs. In the other species of fish, we observed markings across several chromosomes, including non-homologous ones, as observed for the Alambari population, in Hypostomus nigromaculatus [Pansonato-Alves et al., 2013b], Abracris flavolineata [Bueno et al., 2013], and Rhammatocerus brasiliensis [Oliveira et al., 2011]. Cabrero et al. [2009] proposed that the conservation of histone H3 genes found in species of grasshoppers of the genus Acrididae happened prior to evolutionary processes that led 

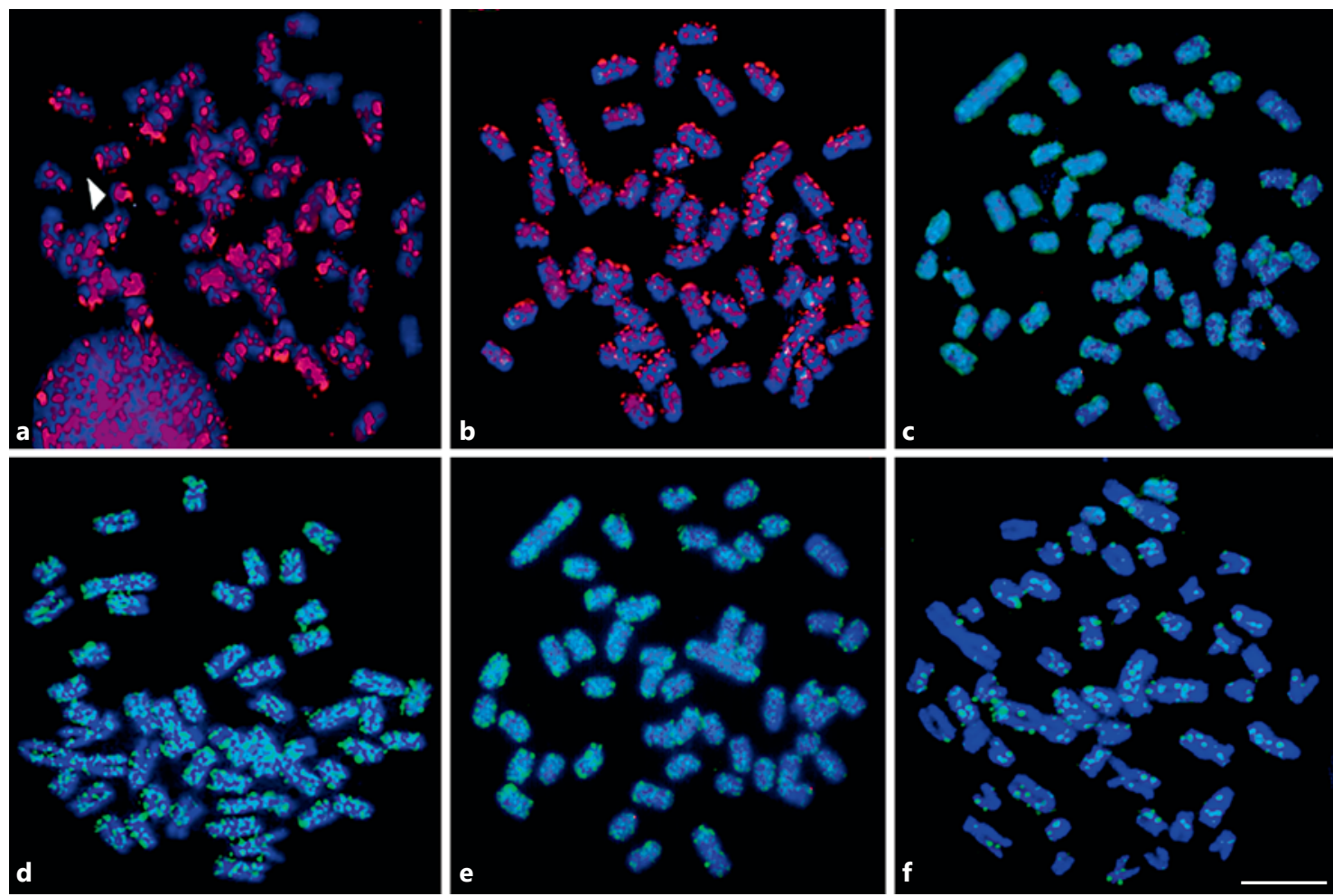

Fig. 3. Mapping of the transposable element Rex 1 in somatic metaphases from individuals of 6 populations of $A$. bockmanni after in situ hybridization. a Alambari River. b Campo Novo Stream. c Barra Seca Stream. d Batalha River. e Capivara River. $\mathbf{f}$ Véu de Noiva Waterfall. Red and green signals indicate the hybridization sites. The arrowhead points to the $\mathrm{B}$ chromosome in $\mathbf{a}$. Bar $=10 \mu \mathrm{m}$.

to the differentiation of these species. This is reinforced by the analysis of clusters of histone $\mathrm{H} 3$ performed in the locus of the family Proscopiidae [Cabral-de-Melo et al., $2011 \mathrm{a}-\mathrm{c}]$ and would be a plausible hypothesis for the populations of A. bockmanni, where similar distribution patterns were observed between populations but with the $\mathrm{H} 3$ genes located on different chromosomes.

Another intriguing class of repetitive DNA elements is represented by transposable elements, especially those comprising the Rex family. In fish, these sequences are found to be compartmentalized in heterochromatic regions or dispersed throughout the genome [Ferreira et al., 2011b; Utsunomia et al., 2014; Yano et al., 2014; Chalopin et al., 2015]. In Hypostomus nigromaculatus, PansonatoAlves et al. [2013b] observed fluorescence signals of transposable elements concentrated as conspicuous blocks on only 3 chromosomes, with small markings dispersed along the remainder of the genome. Similarly, we observed the transposons Rex 1 and Rex6 spread on most chromosomes of the 6 populations of $A$. bockmanni analyzed. However, some chromosomes had tags in the form of large blocks or even smaller markings, which almost completely marked the chromosomes. Such a distribution reinforces the hypothesis that transposons are preferentially located in the heterochromatic regions, possibly because these heterochromatic regions are generally free of natural selection.

Unlike Rex1 and Rex6 which have a similar distribution pattern, Rex 3 was distributed differently between the populations of $A$. bockmanni, being dispersed on most chromosomes or concentrating as large blocks on some chromosomes. Such a distinct pattern of Rex3 dispersion is also reported in the species of Hypoptopomatinae [Ferreira et al., 2011a], Erythrinus [Cioffi et al., 2010], Astyanax [Silva et al., 2013; Pansonato-Alves et al., 2013a], species of the genus Hypostomus [PansonatoAlves et al., 2013b], cichlids [Fantinatti et al., 2012], Antarctic fish [Ozouf-Costaz et al., 2004], and 32 other fish species [Ferreira et al., 2011b]. The fish genome presents a great plasticity and the ability to incorporate transposable elements, attributes that have the potential to lead to intra- and interspecies polymorphisms and copy number 

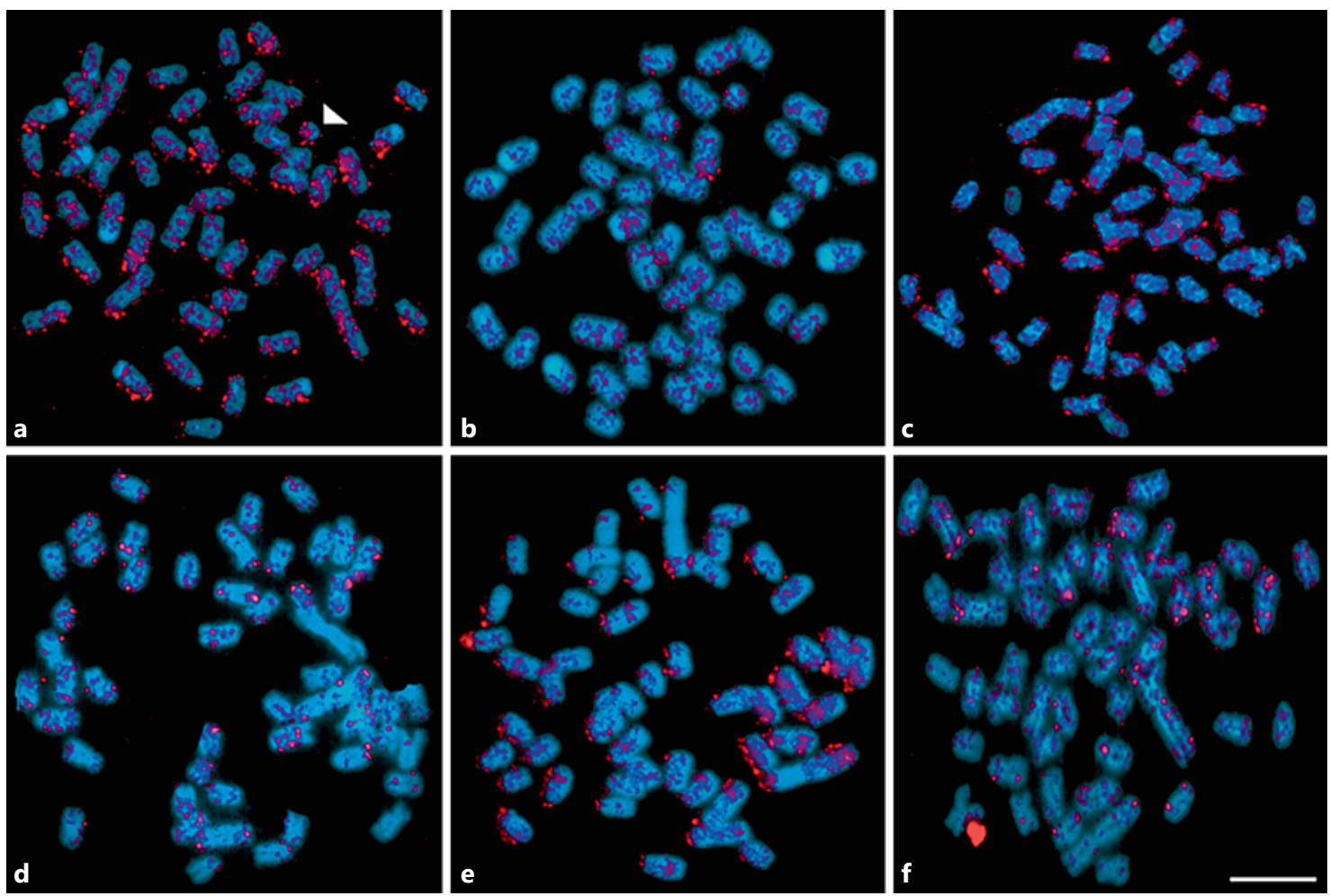

Fig. 4. Mapping of the transposable element Rex6 in somatic metaphases from individuals of 6 populations of $A$. bockmanni after in situ hybridization. a Alambari River. b Campo Novo Stream. c Barra Seca Stream. d Batalha River. e Capivara River. f Véu de Noiva Waterfall. Red signals indicate the hybridization sites. The arrowhead points to the B chromosome in a. Bar $=10 \mu \mathrm{m}$.

variability, thus resulting in large changes in the structure and gene expression [Capy, 1998; Ferreira et al., 2011a].

Additionally, in relation to transposons, Volff et al. [2000, 2001] postulated that the absence or presence of these elements in fish may result from rapid divergence and that these elements degrade, leading to significant changes in their sequences. Additionally, the similarity in the distribution of Rex-type transposons in the genomes of different fish and in the reported populations of $A$. bockmanni imply an origin by horizontal transfer of these elements to this species. Horizontal transfer is the movement of genetic material between genomes of different species without always involving sexual transmission between related species [Loreto et al., 2008]. The literature reports several examples of horizontal transfer, with the most studied cases being in Drosophilidade [reviewed in Loreto et al., 2008] and Drosophila melanogaster [Kidwell et al., 1977; Fischer et al., 2004]. However, other examples are described in Diptera and Neuroptera [Robertson and Lampe, 1995], Coregoninae [Hamada et al., 1997], Myotis lucifugus [Pritham and Feschotte, 2007], ruminants and Squamata [Zupunski et al., 2001], and other vertebrates [Gentles et al., 2007]. Transposons are present in the genomes of most living beings, a factor that suggests a long existence, whereas other active forms of these elements could have existed and persisted in the genome of their hosts, potentially through horizontal transmission. Different authors have suggested that the insertion of transposons may have occurred prior to the speciation process of each species [Aparício et al., 2002] and then evolved jointly [Ferreira et al., 2011a].

According to Volff et al. [2000], the nucleotide sequences of Rex1 retroelements would be associated with multiple ancestral lineages undergoing explosion processes independent of retrotransposition and would then be inserted into the genomes of different fish. Therefore, the acquisition of elements of the Rex type in fish would probably be associated with horizontal transfer following a similar distribution pattern on the chromosomes of species from phylogenetically related groups, suggesting a non-random mechanism of integration, maintenance, 
and evolution of these elements in the genomes of different fish. Variations associated with small deletions, duplications, inversions, and translocations are common among elements of Rex1, Rex3, and Rex6 and can be correlated to the transposition process of these retrotransposons [Cordaux and Batzer, 2009].

For the signals of transposons in $\mathrm{B}$ chromosomes of $A$. bockmanni, the sites of Rex 1 and Rex6 were previously identified in the B chromosomes of Astatotilapia latifasciata [Fantinatti et al., 2012]. In Alburnus alburnus, the transposon Gypsy/Ty3 was found to be located exclusively on the B chromosome [Ziegler et al., 2003; Yano et al., 2014]. Studies involving the sexual differentiation of transposable elements revealed that in Chionodraco hamatus, the transposon Rex3 accumulated on the long arm of the $\mathrm{Y}$ chromosome and, according to the authors, may play a key role in sexual differentiation [Ozouf-Costaz et al., 2004], thus serving an important function in the genome evolution of their hosts and actively collaborating with the biological diversity of these organisms. Similarly, Yano et al. [2014] observed a concentration of Rex1, Rex3, and Rex6 in the Y chromosome of this species. The presence of Rex transposons in the supernumerary chromosome of A. bockmanni could suggest their participation in differentiation and possibly in development of the additional chromosome in this species.

In conclusion, this study provides new information about the behavior of repetitive elements and transposable sequences in the genome of fish. In the 6 populations of A. bockmanni examined certain conservative patterns were observed, and the genomic distributions and behaviors of the histone genes and the Rex6 and Rex 1 transposons were also revealed. The Rex 3 transposon presented a particular dynamism, revealing various distribution patterns among different populations of this species. Therefore, this study contributes to the understanding of the physical location and organization of histone genes $\mathrm{H} 1$ and $\mathrm{H} 3$ and the transposons Rex1, Rex3, and Rex6 in fish genomes, adding new information on the gene composition of the supernumerary chromosome in A. bockmanni.

\section{Acknowledgements}

The authors are grateful to Dr. Cláudio Oliveira for his assistance in the identification of A. bockmanni species and to the Brazilian funding agencies Fundação de Amparo à Pesquisa do Estado de São Paulo (FAPESP) and Coordenação de Aperfeiçoamento de Pessoal de Nível Superior (CAPES) for providing financial support.

\section{References}

Aparício S, Chapman J, Stupka E, Putnam N, Chia $\mathrm{JM}$, et al: Whole-genome shotgun assembly and analysis of the genome of Fugu rubripes. Science 297:1301-1310 (2002).

-Bueno D, Palacios-Gimenez OM, Cabral-de-Mello DC: Chromosomal mapping of repetitive DNAs in the grasshopper Abracris flavolineata reveal possible ancestry of the $\mathrm{B}$ chromosome and $\mathrm{H} 3$ histone spreading. PloS One 8:e66532 (2013).

Cabral-de-Mello DC, Moura RC, Martins C: Cytogenetic mapping of rRNAs and histone $\mathrm{H} 3$ genes in 14 species of Dichotomius (Coleoptera, Scarabaeidae, Scarabaeinae) beetles. Cytogenet Genome Res 134:127-135 (2011a).

-Cabral-de-Mello DC, Cabrero J, López-León MD, Camacho JPM: Evolutionary dynamics of $5 \mathrm{~S}$ rDNA location in acridid grasshoppers and its relationship with $\mathrm{H} 3$ histone gene and $45 \mathrm{~S}$ rDNA location. Genetica 139:921-931 (2011b).

-Cabral-de-Mello D, Oliveira S, Moura R, Martins C: Chromosomal organization of the $18 \mathrm{~S}$ and $5 \mathrm{~S}$ rRNAs and histone $\mathrm{H} 3$ genes in Scarabaeinae coleopterans: insights into the evolutionary dynamics of multigene families and heterochromatin. BMC Genet 12:88 (2011c).
Cabrero J, López-León MD, Teruel M, Camacho JPM: Chromosome mapping of $\mathrm{H} 3$ and $\mathrm{H} 4$ histone gene clusters in 35 species of acridid grasshoppers. Chromosome Res 17:397-404 (2009).

Capy P: Evolutionary biology: a plastic genome. Nature 396:522-523 (1998).

Chalopin D, Naville M, Plard F, Galiana D, Volff JN: Comparative analysis of transposable elements highlights mobilome diversity and evolution in vertebrates. Genome Biol Evol 7: 567-580 (2015).

Charlesworth B, Sniegowski P, Stephan W: The evolutionary dynamics of repetitive DNA in eukaryotes. Nature 371:215-220 (1994).

Cioffi MB, Martins C, Bertollo LA: Chromosome spreading of associated transposable elements and ribosomal DNA in the fish Erythrinus erythrinus. Implications for genome change and karyoevolution in fish. BMC Evol Biol 10: 271 (2010).

Colgan DJ, McLauchlan A, Wilson GDF, Livingston SP, Edgecombe GD, et al: Histone H3 and U2 snRNA DNA sequences and arthropod molecular evolution. Aust J Zool 46:419437 (1998).

-Cordaux R, Batzer MA: The impact of retrotransposons on human genome evolution. Nature Rev Genet 10:691-703 (2009).
Daniel SN, Hashimoto DT, Pansonato-Alves JC, Foresti F, Porto-Foresti F: Cytogenetic characterization of distinct B chromosomes in a population of the fish Astyanax bockmanni (Teleostei, Characiformes). Caryologia 65: 229-233 (2012).

-Daniel SN, Penitente M, Hashimoto DT, Silva DMZA, Foresti F, Porto-Foresti F: New insights into karyotypic relationships among populations of Astyanax bockmanni (Teleostei, Characiformes) of different watersheds. Zebrafish 12:181-188 (2015).

Fantinatti BE, Mazzuchelli J, Valente GT, Cabralde-Mello D, Martins C: Genomic content and new insights on the origin of the B chromosome of the cichlid fish Astatotilapia latifasciata. Genetica 139:1273-1282 (2012).

Fernandes CA, Piscor D, Bailly D, da Silva VFB, Martins-Santos IC: Cytogenetic studies comparing three Characidae fish species from the Iguatemi river basin, Brazil. Caryologia 75: 329-333 (2010).

Ferreira DC, Oliveira C, Foresti F: Chromosome mapping of retrotransposable elements Rex 1 and Rex3 in three fish species in the subfamily Hypoptopomatinae (Teleostei, Siluriformes, Loricariidae). Cytogenet Genome Res 132:64-70 (2011a).
Histone Genes and Transposable

Elements in Astyanax bockmanni
Cytogenet Genome Res 2015;146:311-318 DOI: $10.1159 / 000441613$ 
-Ferreira DC, Porto-Foresti F, Oliveira C, Foresti F: Transposable elements as a potential source for understanding the fish genome. Mob Genet Elements 2:1-6 (2011b).

-Fischer C, Bouneau L, Coutanceau JP, Weissenbach J, Volff JN, Ozouf-Costaz C: Global heterochromatic colocalization of transposable elements with minisatellites in the compact genome of the pufferfish Tetraodon nigroviridis. Gene 336:175-184 (2004).

-Foresti F, Oliveira C, Almeida-Toledo LF: A method for chromosome preparations from large specimens of fishes using in vitro short treatment with colchicine. Experientia 49: 810-813 (1993).

- Gentles AJ, Wakefield MJ, Kohany O, Gu W, Batzer MA, et al: Evolutionary dynamics of transposable elements in the short-tailed opossum Monodelphis domestica. Genome Res 17:992-1004 (2007).

- Gursel I, Gursel M, Yamada H, Ishii KJ, Takeshita F, Klinman DM: Repetitive elements in mammalian telomeres suppress bacterial DNA-induced immune activation. J Immunol 171:1393-1400 (2003).

-Hamada M, Kido Y, Himberg M: A newly isolated family of short interspersed repetitive elements (SINEs) in coregonid fishes (whitefish) with sequences that are almost identical to those of the SmaI family of repeats: possible evidence for the horizontal transfer of SINEs. Genetics 146:355-367 (1997).

-Hashimoto DT, Porto-Foresti F: Chromosome polymorphism of heterochromatin and nucleolar regions in two populations of the fish Astyanax bockmanni (Teleostei: Characiformes). Neotrop Ichthyol 8:861-866 (2010).

- Hashimoto DT, Ferguson-Smith MA, Rens W, Foresti F, Porto-Foresti F: Chromosome mapping of $\mathrm{H} 1$ histone and 5S RNA gene clusters in three species of Astyanax (Teleostei: Characiformes). Cytogenet Genome Res 134:64-71 (2011).

-Hashimoto DT, Ferguson-Smith MA, Rens W, Prado FD, Foresti F, Porto-Foresti F: Cytogenetic mapping of $\mathrm{H} 1$ histone and ribosomal RNA genes in hybrids between catfish species Pseudoplatystoma corruscans and Pseudoplatystoma reticulatum. Cytogenet Genome Res 139:102-106 (2012).

-Kavalco KF, Pazza R, Almeida-Toledo LF: Astyanax bockmanni Vari and Castro, 2007: an ambiguous karyotype in the Astyanax genus. Genetica 136:135-139 (2009).

-Kidwell MG, Kidwell JF, Sved JA: Hybrid dysgenesis in Drosophila melanogaster: a syndrome of aberrant traits including mutation, sterility and male recombination. Genetics 86:813833 (1977).
Levan A, Fredga K, Sandberg AA: Nomenclature for centromeric position on chromosomes. Hereditas 52:201-220 (1964).

Loreto EL, Carareto CMA, Capy P: Revisiting horizontal transfer of transposable elements in Drosophila. Heredity 100:545-554 (2008).

Nagoda N, Fukuda A, Nakashima Y, Matsuo Y: Molecular characterization and evolution of the repeating units of histone genes in Drosophila americana: coexistence of quartet and quintet units in a genome. Insect Mol Biol 14: 713-717 (2005).

Oliveira C, Almeida-Toledo LF, Foresti F, Toledo-Filho SA: Supernumerary chromosomes, Robertsonian rearrangements and multiple NORs in Corydoras aeneus (Pisces, Siluriformes, Callichthyidae). Caryologia 41:227236 (1988).

- Oliveira NL, Cabral-de-Mello DC, Rocha MF, Loreto V, Martins C, Moura RC: Chromosomal mapping of rDNAs and $\mathrm{H} 3$ histone sequences in the grasshopper Rhammatocerus brasiliensis (Acrididae, Gomphocerinae): extensive chromosomal dispersion and co-localization of $5 \mathrm{~S}$ rDNA/H3 histone clusters in the A complement and B chromosome. Mol Cytogenet 4:24 (2011)

-Ozouf-Costaz C, Brandt J, Körting C, Pisano E, Bonillo C, et al: Genome dynamics and chromosomal localization of the non-LTR retrotransposons Rex1 and Rex3 in Antarctic fish. Antarctic Science 16:51-57 (2004).

Pansonato-Alves JC, Hilsdorf AW, Utsunomia R, Silva DMZA, Oliveira C, Foresti F: Chromosomal mapping of repetitive DNA and cytochrome $\mathrm{C}$ oxidase I sequence analysis reveal differentiation among sympatric samples of Astyanax fasciatus (Characiformes, Characidae). Cytogenet Genome Res 141:133-142 (2013a).

-Pansonato-Alves JC, Serrano EA, Utsunomia R, Scacchetti PC, Oliveira C, Foresti F: Mapping five repetitive DNA classes in sympatric species of Hypostomus (Teleostei: Siluriformes: Loricariidae): analysis of chromosomal variability. Rev Fish Biol Fish 1-13 (2013b).

Pinkel D, Straume T, Gray JW: Cytogenetic analysis using quantitative, high-sensitivity, fluorescence hybridization. Proc Natl Acad Sci USA 83:2934-2938 (1986)

-Pritham EJ, Feschotte C: Massive amplification of rollingcircle transposons in the lineage of the bat Myotis lucifugus. Proc Natl Acad Sci USA 104:1895-1900 (2007).

Robertson HM, Lampe DJ: Recent horizontal transfer of a mariner transposable element among and between Diptera and Neuroptera. Mol Biol Evol 12:850-862 (1995).

- Silva DMZA, Pansonato-Alves JC, Utsunomia R, Daniel SN, Hashimoto DT, et al: Chromosomal organization of repetitive DNA sequences in Astyanax bockmanni (Teleostei, Characiformes): dispersive location, association and co-localization in the genome. Genetica 141:329-336 (2013).
-Silva DMZA, Pansonato-Alves JC, Utsunomia R, Araya-Jaime C, Ruiz-Ruano FJ, et al: Delimiting the origin of a $\mathrm{B}$ chromosome by FISH mapping, chromosome painting and DNA sequence analysis in Astyanax paranae (Teleostei, Characiformes). PloS One9:e94896 (2014).

Sumner AT: A simple technique for demonstrating centromeric heterochromatin. Exp Cell Res 75:304-306 (1972).

Utsunomia R, Pansonato-Alves JC, Scacchetti PC, Oliveira C, Foresti F: Scattered organization of the histone multigene family and transposable elements in Synbranchus. Genet Mol Biol 37:30-36 (2014).

-Valente GT, Mazzuchelli J, Ferreira IA, Poletto $\mathrm{AB}$, Fantinatti BE, Martins C: Cytogenetic mapping of the retroelements Rex1, Rex3 and Rex6 among cichlid fish: new insights on the chromosomal distribution of transposable elements. Cytogenet Genome Res 133:34-42 (2011)

-Vicari MR, Nogaroto V, Noleto RB, Cestari MM, Cioffi MB, et al: Satellite DNA and chromosomes in Neotropical fishes: methods, applications and perspectives. J Fish Biol 76:10941116 (2010).

Volff JN, Körting C, Sweeney K, Schartl M: The non-LTR retrotransposon Rex3 from the fish Xiphophorus is widespread among teleosts. Mol Biol Evol16:1427-1438 (1999).

- Volff JN, Körting C, Schartl M: Multiples lineages of the non-LTR retrotransposon Rex1 with varying success in invading fish genomes. Mol Biol Evol 17:1673-1684 (2000).

Volff JN, Körting C, Froschauer A, Sweeney K, Schartl M: Non-LTR retrotransposons encoding a restriction enzyme-like endonuclease in vertebrates. J Mol Evol 52:351-360 (2001).

Yano CF, Bertollo LAC, Molina WF, Liehr T, Cioffi, MB: Genomic organization of repetitive DNAs and its implications for male karyotype and the neo-Y chromosome differentiation in Erythrinus erythrinus (Characiformes, Erythrinidae). Comp Cytogenet 8: 139-151 (2014).

Ziegler CG, Lamatsch DK, Steinlein C, Engel W, Schartl M, Schmid M: The giant B chromosome of the cyprinid fish Alburnus alburnus harbours a retrotransposon derived repetitive DNA sequence. Chromosome Res 11:23-35 (2003).

Zupunski V, Gubensek F, Korkis D: Evolutionary dynamics and evolutionary history in the RTE clade of non-LTR retrotransposons. Mol Biol Evol 18:1849-1863 (2001).

Daniel/Penitente/Silva/Hashimoto/ Ferreira/Foresti/Porto-Foresti 